\title{
Sprawozdanie z XV Konferencji Kaszubsko-Pomorskiej „Mieszkać na Pomorzu. Transformacje lokalnych i regionalnych tożsamości pomorskich", 14-15 listopada 2019 roku, Słupsk
}

Kolejną, piętnastą już edycję konferencji naukowych dotyczących problematyki regionu Kaszub i Pomorza zorganizowało Muzeum Pomorza Środkowego przy wsparciu merytorycznym Instytutu Etnologii i Antropologii Kulturowej Uniwersytetu im. Adama Mickiewicza w Poznaniu. Podczas tegorocznego spotkania podejmowane dyskusje i wygłaszane referaty odnosiły się do kwestii tożsamości pomorskiej, dokładniej tożsamości ludności lokalnej i regionalnej Pomorza dawniej i współcześnie. Wielokulturowy charakter wspomnianego regionu nieustanne pobudza do refleksji nad procesami kształtowania (odnajdywania, uświadamiania, negocjowania) tożsamości. Szczególną rolę w tym kontekście odgrywają pamięć oraz sposoby posługiwania się nią, zarówno przez jednostki, jak i grupy lokalne i regionalne. Tak szerokie zagadnienie rozpatrywano ze zwróceniem uwagi na aspekty: tożsamości społeczeństw współczesnych, w tym miejskich, na Pomorzu, wpływu ruchów społeczno-politycznych (np. z lat siedemdziesiątych czy osiemdziesiątych XX wieku) na tożsamość, tożsamości z perspektywy organizacji pozarządowych oraz z perspektywy muzeów, które miejscowe dziedzictwo kulturowe tłumaczą i wybierają z niego to, co znaczące z punktu widzenia tożsamości grupowej.

Spotkania odbywające się podczas dwóch kolejnych dni konferencji, w pięciu blokach tematycznych, otworzyły wystąpienia badaczek i badaczy próbujących odpowiedzieć na pytania dotyczące współczesnych procesów kształtowania się tożsamości lokalnej i regionalnej na Pomorzu. Jako pierwsza wystąpiła Aleksandra Paprot-Wielopolska z referatem „Postmigracyjna lokalność czy regionalność? O wymiarach współczesnej tożsamości na Żuławach i Powiślu”. Barbara Borzyszkowska 
i Anna Kwaśniewska przybliżyły to zagadnienie na podstawie studiów przypadku, poświęconych, odpowiednio, regionowi bytowskiemu („Pogranicze bytowskie, czyli we współczesnym wielokulturowym tyglu”) i Kosznajderii („Re(konstrukcja) tożsamości pomorskiej: przypadek Kosznajderii”). W dwóch kolejnych referatach podjęto temat tożsamości ludności autochtonicznej zamieszkującej badany obszar oraz roli jej dziedzictwa kulturowego. Małgorzata Zawiła poświęciła uwagę zagadnieniu: „Dziedziczynienie przedwojennych cmentarzy jako element tworzenia lokalnej tożsamości na Pomorzu”, natomiast Zbigniew Sobisz podjął temat: „O asymilacji kulturowej i tożsamości Niemców na Ziemi Lęborskiej w latach powojennych”.

Kolejna sesja była poświęcona procesom tożsamościowym na Kaszubach oraz czynnikom, które tym procesom sprzyjają. Prelegenci omówili takie zjawiska, jak religijność ludowa (Andrzej Stachowiak: „Specyfika praktykowania religii przez Kaszubów na przykładzie "pokłonów feretronów"), język kaszubski (Daniel Kalinowski: „Naznaczeni winą - unoszeni wizją. Najnowsze pokolenie piszących po kaszubsku”), taniec (Maria Aleksandrowicz: „Znaczenie tańca dla tożsamości Kaszubów - co motywowało i motywuje, że ludzie tańczą?"), poczucie tożsamości (Monika Mazurek: „Kaszubi czyli kto? - analiza procesu kreowania tożsamości”). Mariusza Filipa przedstawił wyniki badań terenowych prowadzonych na Kaszubach („Życie na dawnych ziemiach Słowińców w świetle badań terenowych”).

Pierwszy dzień konferencji zamykały wystąpienia badaczy reprezentujących spojrzenie „z zewnątrz” na problem wielokulturowości regionu Pomorza oraz związane z nią zróżnicowanie procesów tożsamościowych. Anna Drożdż przybliżyła zasoby archiwalne Polskiego Atlasu Etnograficznego, które dla zainteresowanych mogą stanowić dodatkowe źródło wiedzy na temat powojennych losów mieszkańców wybranych miejscowości pomorskich. Aleksandra Gałka-Kopera, na podstawie analizy materiałów terenowych, wskazała na te elementy dziedzictwa kultury jamneńskiej, które mogą stać się ważnym składnikiem tożsamości lokalnej mieszkańców. Szczególną uwagę skupiła na potencjale budownictwa szachulcowego, jako elementu kształtującego tożsamość lokalną mieszkańców, jak również składowej lokalnego produktu turystycznego. W wystąpieniu „Pamięć wędruje z ludźmi: przemiany tradycji muzycznych (na przykładzie Pomorza Zachodniego)” Ewa Grochowska omówiła specyfikę tradycji muzycznych na Pomorzu Zachodnim, wyjątkowość ich przekazu i problematyki oraz znaczenia w budowaniu tożsamości kulturowej mieszkańców tego regionu obecnie. Jako ostatni głos zabrali Magdalena Zdrowicka-Wawrzyniak i Karol Walczak. Badacze zaprezentowali postać i działalność Karoli Bober z Lipusza, lokalnej producentki tradycyjnego pieczywa, działaczki regionalnej i edukatorki. Wskazali, jaką rolę odegrały jej działania w procesie zachowania i (re)konstrukcji miejscowego dziedzictwa kulturowego, a w rezultacie również w procesie kreowania lokalnej tożsamości.

Drugi dzień konferencji otworzyły wystąpienia przybliżające niejednoznaczną rolę i znaczenie instytucji państwowych (w tym oświatowych) w procesie kształtowania tożsamości regionalnej. Anna Weronika Brzezińska w referacie 
„Walka o tożsamość. Kroniki szkolne z Pomorza jako źródło wiedzy o strajku szkolnym w latach 1906-1907" przedstawiła wyniki analizy wpisów pochodzących z 40 kronik szkolnych, a dotyczących strajku szkolnego, który odbył się na obszarze inspektoratu szkolnego w Tczewie. Treści wspomnianych zapisów zanalizowała $\mathrm{w}$ świetle koncepcji miejsc pamięci oraz pamięci zbiorowej i społecznej. Adam Czarnecki skupił się na zaprezentowaniu wyników badań na temat przeprowadzonej w Polsce w latach 1948-1956, w wyniku decyzji powojennych władz kraju, kolektywizacji rolnictwa oraz postaw mniejszości narodowych Pomorza Środkowego wobec tej polityki. Marcin Owsiński omówił współczesną rolę muzeum $\mathrm{w}$ procesie budowania tożsamości regionalnej. Wnioski oparł na doświadczeniu własnym, jako wieloletniego pracownika Muzeum Stutthof i koordynatora autorskiego projektu serii działań i wydawnictw popularyzujących najnowszą historię Żuław i regionu Pomorza. Ostatnie wystąpienie w sesji czwartej, „Zagubiona tożsamość a pomorskie doświadczenie domu. Blok i chata”, Agnieszka Kurkowska poświęciła architekturze jako zjawisku kulturotwórczemu i istotnie wpływającemu na odczuwanie tożsamości lokalnej, regionalnej; omówiła konstruowanie pojęcia „domu” przez mieszkańców tego regionu, które określa, z jednej strony, tradycyjna kaszubska zabudowa wiejska, z drugiej, współczesne pomorskie osiedle.

Sesja piąta, kończąca drugi dzień konferencji, oscylowała wokół zagadnień historycznych. Jako pierwszy wystąpił Andrzej Chludziński z obszernym przeglądem nazw miejscowych na Pomorzu („Nazewnictwo miejscowe na Pomorzu w ciągu ostatnich tysiąca lat jako wyraz tożsamości etnicznych i kulturowych"). Justyna Żukowska w referacie „Wpływ kultury miejskiej na tożsamość mieszkańców miast Prus Królewskich w XVI-XVII wieku" przedstawiła proces kształtowania się kultury mieszczańskiej i tożsamości mieszczańskiej. Kacper Pencarski w swoim wystąpieniu skupił się na społeczno-gospodarczych konsekwencjach modernizacji lokalnej sieci dróg oraz budowy sieci linii kolejowych (normalnoi wąskotorowych) w południowej części dawnego powiatu sławieńskiego. Krystyna Krawiec-Złotkowska poruszyła zagadnienie: „Transformacje tożsamościowe mieszkańców Słupska utrwalone w pomnikach powstałych przed i po 1945 roku". Prelegentka przybliżyła okoliczności powstania pomników oraz ich przedwojenne i powojenne losy. Konferencję zamknęło wystąpienie Zenona Romanowa na temat: „Kaszubi i Krajniacy a wybory do Sejmu i rad narodowych w województwie koszalińskim w latach 1950-1975”.

Biorąc pod uwagę interdyscyplinarność ujęć problemu wyznaczonego przez organizatorki oraz różnorodność wątków pojawiających się zarówno w trakcie kolejnych wystąpień, jak i w następujących po nich dyskusjach, można stwierdzić, że temat pomorskich tożsamości jest niezwykle aktualny. 
